\title{
Management of Covid-19 patients with indigenous formulations in home settings- Case reports of two patients
}

\author{
Neeta Kumar, ${ }^{1}$ Nalini Tripathi, ${ }^{2}$ Mukesh Nandave $^{3}$ \\ ${ }^{1}$ Scientist-E, Indian Council of Medical research (ICMR) Head Quarters, New Delhi \\ ${ }^{2}$ Scientist-C, Department of Community Medicine, Vardhman Mahavir Medical College \& \\ Safdarjung Hospital, New Delhi, \\ ${ }^{3}$ Professor, Pharmacology, Delhi Pharmaceutical Sciences and Research University \\ (DPSRU), New Delhi, India
}

\begin{abstract}
:
This is to report 2 cases experiencing action of indigenous medicine in controlling Covid-19 symptoms in the home setting, without any requirement of hospitalization. Covid-19 (SARS-CoV-2), a viral disease by novel coronavirus, impacted 220 countries. Although, numerous attempts have been made for the management and treatment of Covid-19 with various drugs, traditional Ayurveda and Siddha has been widely reported to be effective in treating viral diseases through altering innate adaptive immune response and inhibition of virus attachment to body cells. It is found to inhibit attachment of virus to human cell, hence reducing viral load induced cytokine storm, inflammatory over reactions in the body of patients and inhibition of community spread. The experience of 2 cases reported here showed how senior citizens with various co-morbidities recovered from covid 19 and remained healthy without sequelae or side effects even after 6 months of follow-up. These observations are vital clues for a large population-based study and ongoing clinical trials. Mechanism of action of Sidha and Ayurvedic medicines like Kabasura Kudineer, Sitopladi, Triphala are well published and highly recommended for affecting viral entry and immune regulatory pathways. With no side effects, secondary infections and action, these regimens pave the ways for safe and effective cure for Covid-19.
\end{abstract}

Keywords: Antiviral, Ayurveda, Covid-19, inflammatory response, medicinal herbs, Siddha medicine.

Received: 16.04.2021 Revised: 08.05.2021 Accepted: 24.06.2021 Published: 28.06.2021

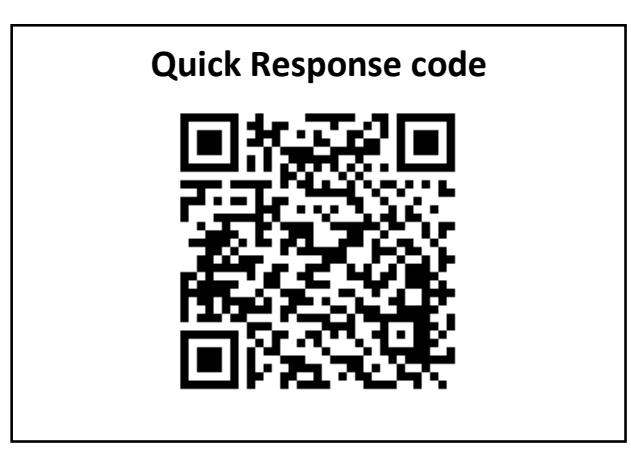

*CORRESPONDING AUTHOR:

Dr Neeta Kumar,

Scientist E, ICMR Hqrs, Room no 214, First floor

Indian Council of Medical Research, Ansari Nagar,

New Delhi-110029.

Email neetakumar50@gmail.com 


\section{Introduction:}

With second wave March 2021 onwards, globally 17.9 crores persons suffered and 38.8 lakhs deaths with India reporting 3.91 lakhs deaths ranking 2nd in prevalence, 3rd in Deaths. [ ${ }^{1]}$ Appropriate and timely action of prevention and management by Government of India helped during first wave of Covid-19 pandemic. However People living with preexisting health conditions such as heart disease, diabetes, and respiratory conditions were considered at higher risk of complications, sequelae, and death due to Covid-19. Hence reporting is highly needed about the response observed in such high risk cases with use of Indian Sidhha, Ayurvedic traditional formulations to manage fever, cough, body-ache of Covid-19. $\left.{ }^{2}\right]$

\section{Case 1: Patient description}

This is about a case of senior citizens, female aged 64 years having co-morbidities of heart disease (coronary artery diseases-CAD), and arthritis and were found having high grade fever, headache, body ache, difficulty in breathing. Diagnosis of Covid-19(SARS-CoV2) infection was confirmed by real-time Reverse Transcriptase Polymerase Chain Reaction (RT-PCR) nasopharyngeal swabs on 20 September 2020. She had no history of contact however visited a public gathering of 40-50 persons in an open park, 3 days ago.

\section{Case history of case 1:}

The patient living in South Delhi, belonging to an upper-middle socio-economic group, having arthritis for 24 years, coronary artery disease 14 years, had sudden onset of high fever $\left(102^{\circ} \mathrm{F}\right.$ to $\left.104^{\circ} \mathrm{F}\right)$ with severe body ache, fatigue, breathlessness, sore throat since 17 September 2020. She underwent tests at the Government health facility after 2 days of uncontrolled symptoms where she was diagnosed positive for Covid-19. Results of pathological tests showed raised CRP at 184 $\mathrm{mg} / \mathrm{L}$ and ferritin 116000ng/ml. D dimer level was $1200 \mathrm{ng} / \mathrm{ml}$ indicative of severe inflammation. Pulse oxymeter showed $78 \%$ oxugen, pulse rate 120/minute. An absolute lymphocyte count was lower than normal range -950cells/ $\mu$.

\section{Treatment prescribed:}

The patient consumed tablet Paracetamol (500 mg three times a day) for high fever, along with steam inhalation from day one of the symptoms. After the diagnosis of Covid-19, on third day of fever, she was advised for home quarantine with the added treatment of Doxycyclin, Vitamin C, Azithromycin, ZnSo4, fluids, and juices, which she complied without any relief in symptoms. On $5^{\text {th }}$ day of continued high-grade fever, she consumed two tablets of Kabasura Kudineer, Sitopladi, Triphala, Amruta (Giloy) (500 mg tablets of each twice a day) with warm water on 22 September. After consuming she started feeling relief of symptoms instantly and became completely symptom free by the next day. She continued treatment for 7 days. No further complication or residual symptoms remain till date, post 6 months of her Covid-19.

\section{Case 2: Patient description:}

A male aged 68 years living in East Delhi, is a known hypertensive, diabetic and suffering from coronary artery disease and on regular medications- Atenolol $25 \mathrm{mg}$, Glyciphage 500 $\mathrm{mg}$, Disprin $325 \mathrm{mg}$, and simvastatin $10 \mathrm{mg}$ twice a day for his illnesses.

\section{Case history of case 2:}

$\mathrm{He}$ had a history of attending a public gathering of a relative's cremation 3 days ago. His symptoms started with high-grade fever, headache, and weakness on $17^{\text {th }}$ September 2020. On examination: The temperature was $102^{\circ} \mathrm{F}$ to $104^{\circ} \mathrm{F}$ with transient dips after taking paracetamol, but no regular relief from symptoms for 3 days. On day 3 i.e. $20^{\text {th }}$ 
September 2020, results of pathological tests came as positive for COVID-19. Serum SARS-CoV-2IgG was -17.00. He was tested for complete blood count, liver, kidney function tests, thyroid profile, urine routine microscopic, lipid profile, blood sugar as prescribed by a local physician. All reports were within normal range except mild rise of lymphocytes as $46 \%$ against reference range of $20-40 \%$ of DLC.

\section{Treatment Prescribed:}

Oral Paracetamol $500 \mathrm{mg} 4$ hourly for 3 days then Azythromycine 500mg two times a day (BD) after food Hydroxychloroquine $500 \mathrm{mg}$ (BD) and Tab Vitamin C $500 \mathrm{mg}$ (BD) from $3^{\text {rd }}$ day after getting Covid 19 test report. After no relief from fever, headache and body ache on $5^{\text {th }}$ day, he was advised Kabasura Kudineer (500 mg,1 tab BD), Sitopaladi (500 mg, 1 tab BD) and Triphala tablets (500 mg, 1 tab BD) for 7 days. Immediately after consuming the regimens, symptoms of Covid-19 started reducing in severity. His fever reduced on 24 th September 2020, and symptoms completely dissolved on $2^{\text {nd }}$ day of consumption of Siddha-Ayurvedic medicines. No further complications and residual illness were observed till $6^{\text {th }}$ month post-Covid-19.

\section{Discussion:}

Age more than $60 \mathrm{yr}$ with presence of diabetes and hypertension were significantly associated with severe COVID-19 disease and 3 patients died $(2.6 \%$ mortality) when clinical characteristics and outcomes compared for adult Covid-19 positive patients admitted to tertiary care hospital at Chandigarh, India, from April 1 to May 25, 2020 Patients with co morbidities were found more vulnerable to complications also. ${ }^{[3]}$ The cases reported here are important in view of the advanced age and comorbid conditions, severity of symptoms and their ongoing treatments considered as high-risk conditions at the time of Covid-19 infection. ${ }^{[3]}$

In India recovery from Covid-19 remains high as on $23^{\text {rd }}$ June 20212.91 crore of Covid 19

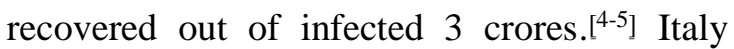
with $9.26 \%$ death tops the cross country fatality rates (CFR). CFR of China was 3.9\% and $2.8 \%$ in India. Apart from timely preventive measures undertaken by The Government of India the sharp difference of mortality across country data warrants evaluation of treatment stretegies. ${ }^{[4]}$ Review of pathological changes in autopsy findings of patients with COVID-19 show endothelial damage and formation of microthrombi with multi-organ involvement and, ultimately, multi-organ failure; However trials did not prove that, Covid-19 patients had increased thrombotic risk, despite being treated with heparin despite its anti-coagulant effect. Hence cytokine storm and inflammations generated by Covid-19 virus need different approach of treatment..$\left.^{6}\right]$

Review of the existing literature for pathology mechanism, shows that Covid-19 strain was causing a sharp rise in inflammatory reactions in the form of cytokine storm resulting in disseminated intravascular coagulation in the brain (stroke) or heart (infarct), lung (reduced oxygen -hypoxia, presenting as atypical pneumonia) and related complications. ${ }^{[6]}$ Existing reports and research findings show that age old Indian/indigenous regimens effectively curtail inflammatory overreactions, multisystem inflammatory syndrome, thrombi formation happening due to allergens and viral infections. ${ }^{[7-8]}$ Ingredients of regimen (Kabasura Kudineer, Triphala, Sitopladi) used by two cases reported here were reviewed from published literature and mentioned in Table 1,2 and 3. 
INTERNATIONAL JOURNAL OF AYUSH CASE REPORTS (IJA-CARE)

Table-1: Ingredients of Kabasura Kudineer and their actions: [9-11]:

\begin{tabular}{|llll|}
\hline Sanskrit name/ & Common name/ & Botanical name/ & Active ingredient \\
\hline Chukku/ & Ginger/ & Zingiberofficinale/ & Zingiberene \\
\hline Thippali/ & Pippali / & Piper longum/ & piperine \\
\hline Lavangam/ & Clove / & Syzygiumaromaticum/ & eugenol \\
\hline Cirukanchoriver/ & Dusparsha / & Tragiainvolucrata/ & Costunolide \\
\hline Akkirakaramver/ & Akarakerebha/ & Anacycluspyrethrum/ & Pyrethrin \\
\hline Muliver/ & Kokilaksha/ & Hygrophilaauriculata/ & Apigenin \\
\hline Kadukkaithol/ & Haritaki/ & Terminaliachebula/ & Chebulic acid \\
\hline Adathodeielai/ & Mdabarnut/ & Adhatodavasica/ & Vasicine \\
\hline Karpooravalli/ & Ajwain/ & Coleus amboinicus/ & Myrtenol \\
\hline Kostam/ & Kusta/ & Saussurealappa/ & Costunolide \\
\hline SeenthilThandu/ & Guduchi / & Tinosporacordifolia/ & CordifolisideB \\
\hline Siruthekku/ & Bharangi & Clerodendrumserratum/ & Cavacol \\
\hline Nilavembu/ & Kalmegha & Andrographispaniculata/ & Andrographaide \\
\hline Vattathiruppiver/ & Rajapata/ & Sida acuta/ & Carvacol \\
\hline Koraikizhangu/ & Musta/ & Cyperus rotundus/ & Amentoflavone \\
\hline
\end{tabular}

Table-2: Triphala Ingredients: ${ }^{[12]}$

\begin{tabular}{|l|l|l|l|}
\hline Sanskrit name & Common name & Botanical name & Active ingredient \\
\hline Amalaki & Amla & $\begin{array}{l}\text { Phyllanthus } \\
\text { emblica }\end{array}$ & $\begin{array}{l}\text { Ascorbic acid, Gallic acid, } \\
\text { Nicotinic acid, Ellagic acid, Linoleic } \\
\text { acid,Linolenic acid }\end{array}$ \\
\hline Bibhitaki & Baheda & $\begin{array}{l}\text { Terminalia } \\
\text { bellirica }\end{array}$ & $\begin{array}{l}\text { Gallic acid, Tannic acid, Ascorbic acid, } 3- \\
\text { sitosterol, Ellagic acid, Chebulic acid, } \\
\text { Mannitol, Oxalic acid, Galloyl, Galactose, } \\
\text { Fructose }\end{array}$ \\
\hline Haritaki & Harad & $\begin{array}{l}\text { Terminali } \\
\text { achebula acid, Tannic acid, Syringic acid, } \\
\text { Epicatechin, Ascorbic acid, Chebulinic } \\
\text { acid, Anthraquinone, Phosphoric acid }\end{array}$ \\
\hline
\end{tabular}

Table-3: Sitopaladi Ingredients: ${ }^{[13]}$

\begin{tabular}{|l|l|l|l|}
\hline Sanskrit name & Common name & Botanical name & Active ingredient \\
\hline Twak bark & Tejpatta & Cinnamomum zeylanicum & Cinnamaldehyde \\
\hline Ela seed & Elayachi & Elettaria cardamomum & Cardamom \\
\hline Pippali fruit & Pippali & Piper longum & Piperine \\
\hline Vamsalochan & & Siliceous Concretion & \\
\hline Sharkara & Cane sugar & Saccharum officinarum & Carbohydrate \\
\hline
\end{tabular}

Ingredients combined in equal proportions of $6.66 \%$ of each compound. Ingredients are tested for actions like Antibacterial Anti-viral Anti-inflammatory Antioxidant Hepatoprotective Anti-cancer Neuroprotective Antimicrobial Anti-parasitic Anti-asthmatic Anti-malarial Antihelminthic Antidiabectic
Antifungal Antispasmodic Antipyretic Analgesic Cytoprotective Immunomodulatory Anticonvulsant Antihyperglycemic Abortifacient Wound healing Hypoglycaemic Cytotoxic Antiseptic Antimelanogenic and show different level of part or some of the actions of these ingredients ${ }^{[14,-16]}$. 
Ministry of AYUSH guidelines mention about Kabasura Kudineer as effective Siddha medicine consisting of 15 herbal ingredients, each of them having unique characteristic features of its own. ${ }^{[8]}$ This composition is extensively aimed for boosting the lungs, improving respiratory mechanism and treating infectious conditions like cough, cold, fever and other respiratory infections. ${ }^{[2]}$ This composition became quite well-known during the times of flu in past, owing to its therapeutic and curative qualities.

Many studies have documented antiInflammatory, antipyretic and antibacterial properties of Kabasura Kudineer Choornam. ${ }^{[14-16]}$ Effect of aqueous extract of Kabasura kudineer choornam (AEKKC) have shown significant anti-inflammatory, antipyretic and antibacterial activity evaluated in Coimbatore. AEKKC showed significant in vitro anti-oxidant activity by terminating the actions of free radicals. The AEKKC (200 $\mathrm{mg} / \mathrm{kg}$ and $400 \mathrm{mg} / \mathrm{kg}$ ) studied for its antiinflammatory activity using carrageenan and histamine-induced inflammation as compared to paracetamol $(150 \mathrm{mg} / \mathrm{kg}$ ), Diclofenac (20 $\mathrm{mg} / \mathrm{kg}$ ) as the standard for the antipyretic activity in Brewer's yeast-induced pyrexia model proved AEKKC possesses significant $(\mathrm{P}<0.05)$ anti-inflammatory activity which was evident with a reduction in mean paw edema volume in both carrageenan and histamineinduced inflammatory models. The potential activity of extract considered due to the presence of phenols, flavonoids, and other phytochemical constituents present in it. ${ }^{[14]}$

Screening of Kabasura Kudineer against COVID-19 through targeting of main protease and RNA-dependent RNA polymerase of SARS-CoV-2 by Molecular Docking Studies provided the evidence for the action of 74 different constituents of this formulation acting on two critical targets. ${ }^{[16]}$ That is the main protease and SARS-Cov-2 RNAdependent RNA polymerase target through molecular docking experiments. The molecular docking was done by using AutoDock Tools 1.5.6. Of the 74 compounds 50 compounds yielded docking results against COVID-19 main protease while 42 compounds yielded against SARS-cov2 RNAdependent RNA polymerase. This research has concluded that AEKKC has the lead molecules that inhibit COVID-19's target of the main protease and SARSCov-2 RNA-dependent RNA polymerase. ${ }^{[16]}$

Triphala (tri $=$ three and phala $=$ fruits) (Chinese term San-Teng), is composed of three equal proportions of fruits of all 3 ingredients. [17]. Triphala a polyherbal formulation shows inhibitory activity on microbial growth caused by Streptococcus mutans and Lactobacillus. Ayurvedic formulations like triphalamashi exhibit antimicrobial activity attributed to phenolic compounds and tannins in triphala ${ }^{[1]}$. The oral administration of triphala found reducing the blood sugar, various applications in medical field like laxative, eye rejuvenator, antiinflammatory, antiviral, found effective in headache, dyspepsia, ascites, leucorrhea, also used as a blood purifier analgesic, antiarthritic, and anti -aging properties. It is also prescribed for fatigue, to reduces oxidative stress and infectious diseases such as tuberculosis, pneumonia, AIDS, periodontal diseases. due to oxidative stress. $\left.{ }^{[18}\right]$

Sitopaladi claimed to have an antihistaminic effect, Immunomodulatory, Antiinflammatory, Antibacterial, Adaptogenic,fights against allergies by inhibiting the release of histamines, inflammatory mediators from mast cells in our body and stabilizes them, Digestive And Appetizer by carminative action. Anti-tussive activity of this medication is assign to its ability to affect the central nervous system and suppress a cough, reduces Inflammation and Free Radicals- damaging effects of free radicals, improve anemia due to sub-chronic inflammation, has strong $\alpha$-amylase inhibition activity to prevent the body from absorbing 
starches, thus prevent the spike in blood sugar after meals and controlling postprandial hypoglycaemia. $\left[{ }^{19}\right]$

Apart from above formulations, there are many other such anti-inflammatory, antimicrobial formulations described in Ayurveda considering age gender, prakriti, comorbidity and ongoing treatments, stage of disease.[20] There was state policy of Tamilnadu Government for distribution of KabasuraKudineer. ${ }^{[21]}$ Guidelines of Ministry of AYUSH, Government of India also issued guidelines to promote use of the indigenous herbs for Covid-19 prevention/ management however its implementation scale and community use data should be collected at large scale.

There are studies reporting faster recovery using indigenous methods. ${ }^{[19]}$ Randomised Controlled Trials (RCTs) registered on clinical trial registry (i.e. CTRI registration number: CTRI/2020/06/025800) have evaluated the efficacy of Ayurveda in the management of 120 mildly affected Covid-19 cases using Vyaghryadi, Pippali, Shunthi (Zingiber officinale Rosc.) and Guduchi (Tinospora cordifolia).

Jaipur study (CTRI/2020/05/025273) Traial with $1 \mathrm{~g}$ of Giloy Ghanvati (Tinospora cordifolia) and $2 \mathrm{~g}$ of Swasari Ras (traditional herbo-mineral formulation) and $0.5 \mathrm{~g}$ each of Ashwagandha (Withania somnifera) and Tulsi Ghanvati (Ocimum sanctum) Anutaila (nasal drops) quantified serum levels of interleukin-6 (IL-6), tumor necrosis factor-alpha (TNF- $\alpha$ ), and high sensitivity C-reactive protein (hsCRP)-to predict severity and survival on day 1 and day 7 and found 20 times lesser than those in the placebo group.[22] Community spread possibility was lower with Ayurvedic indigenous medicine group as they become negative at faster pace ${ }^{[22]}$

Auyrvedic and Siddha preparations when compared with Remdesivir, $100 \%$ recovery within 7 days with Ayurvedic/ siddha treatment as compared to 15 days with Ramdesivir. [22-24] One RCT comparing done with combination of Siddha drugs Vasantha kusuma

karammathirai, Thippilirasayanam, Adathodai manapagu and Kabasurakudineerat Omandurar Government Medical College Hospital Tamilnadu showed accelerated recovery with Kabasurakudineer for Covid - 19 patients as compared to standard treatment Group. The Siddha medicines like Kabasurakudineer and Adathodaimanapagu qu oted in classical Siddha texts are approved by Drug and Cosmetic Act. The Siddha Formulary of India, Part I is published by Department of Health and Family Welfare, Government of India. Higher recovery percentage was recorded in In another recent study group on Siddha add-on showed better recovery $(66.67 \%)$ when compared with standard treatment alone $(22.67 \%)^{[24-25]}$.

Where, Hydroxychloroquine (HCQ), Remdesivir, plasma therapies found ineffective and moved out of guidelines, the indigenous herbs showing promising outcomes with survival and reduced community spread are considered now. ${ }^{[24-26]}$ Due to outcome of such studies, many more are now ongoing/ exploring and documenting effect of Siddha ayurvedic preparations like Kabasura, triphala. At CTRI, currently 67 trials are ongoing with traditional medicines. Three studies are exclusively for therapeutic efficiency of Kabasura Kudineer. ${ }^{[27]}$

Most of the community data is missed due to absence of home based data collection system. Only one ICMR Task Force study of health account scheme collected community end data of fever, Flu like illnesses. Despite many high risk factors for India (i.e. dense population, social distancing difficulties due to close and highly knitted social structure, younger age nation, genetic predisposing factor in terms of low $\mathrm{D}$ allele frequencies in Asian, mutation in terms of high virulent virus type, 'B', prevalent in patients across East Asia, low 
inherent immunity, climate of India not favouring Covid-19) lower mortality is observed $(14.5 \%$ in Italy versus $3.17 \%$ of India). ${ }^{[27-28]}$ The comparison of treatment strategies is not done sufficiently so credit of low mortality, difference of outcome due to various management system, indigenous regimens require large scale community and hospital based data comparing home (using traditional) versus standard managements and its outcome, hence studies with proper design are required.

\section{Conclusion:}

Considering observations from the cases, reported here and circumstances of Covid 19 pandemic the evidence-based use of indigenous medicines should be considered for management.

\section{Limitation of study:}

- In the cases reported here both the cases did not repeat Covid 19 test after becoming symptom free (facility of home test was not available that time) hence time taken in becoming Covid 19 negative is not recorded, however symptoms resolved in one day time in both the cases.

- There is mixing of other regimens like paracetamol etc in initial 3-4 days hence role of Siddha- Ayurvedic medicines as stand-alone regimens will be clearer if treated on these medicines from the very beginning of symptoms. More clinical and community data on this is required.

- Though no side effects reported in cases reported here upon taking indigenous composition however, it is always best to seek the advice of an Ayurvedic physician.

- In our cases this formulation was found safe while it was consumed with allopathic medicines and medicines for ongoing chronic co-morbidities however proper pharmacokinetic studies are required to verify it.

\section{Consent of Patients:}

Consent of Both cases has been taken to report their case without their identifier personal details disclosure.

\section{Acknowledgment:}

Sri Sritattva to provide medicines and Both Senior citizens giving details of illness, tests, treatment and consent to remain in follow-up and report experience.

\section{References:}

1. https://www.worldometers.info > coronavirus. [last accessed on 23 June 2021]

2. https://www.ayush.gov.in/docs/siddhaguidelines.pdf. [last accessed on 16 April 2021]

3. Jain $\mathrm{KV}$, Iyengar $\mathrm{KP}$, Vaish $\mathrm{A}$ et al. Differential mortality in COVID-19 patients from India and western countries. Diabetes\& Metabolic Syndrome: Clinical Research \& Reviews 2020;14:1037e1041

4. Morteza A tifKhafaie, Fakher R, Osong. Cross-Country Comparison of Case Fatality Rates of COVID-19/SARS-COV2. Public Health Res Perspect 2020;11(2):74-80

5. Samaddar A, Gadepalli R, Nag VL, Misra S. The Enigma of Low COVID-19 Fatality Rate in India. url:///C:/Users/ICMR/Downloads/fgene11-00854.pdf

6. Parasher A. COVID-19: Current understanding of its Pathophysiology, Clinical presentation and Treatment Postgraduate Medical Journal 2021;97:312-320

7. The pharmacological potential of plant compounds and preparations in COVID-19: A PTR virtual issue. Ester Pagano. Phytotherapy

Research, 10.1002/ptr.6961. urlhttps://www.worldometers.info/coronaviru s/country/india/. [last accessed $17 \mathrm{Feb}$ 2021] 
8. Pradeep K, ReshmaMA. Management of COVID-19 Patients with Mild and Moderate Symptoms through Ayurveda: A Case Series. Int. J. AYUSH CaRe. 2020; 4(4):238-244.

9. Kumar PM, Sundaram M, Ramasamy M.S. Coronavirus spike (S) glycoprotein (2019-ncov) targeted siddha medicines kabasurakudineer and thonthasurakudineer -in silico evidence for corona viral drug. Asian J. Pharm. Res. Health Care, 2020;1(12): 20-27.

10. J. Saravanan. Anti-Inflammatory, Antipyretic and Antibacterial Study of Kabasura Kudineer Choornam. International Journal of Current Advanced Research. 2018; 07(2): 9992-9997.

11. Plant authority: Siddha formulary of India Part II, The controller of Publications, Delhi. 2011;P-160,173,178, 179,181183,186,187,191,192. 12.

12. Plant Authority-Agniveśa, Cakrapidatta, Śarm RM, Dash B. Agniveaś's Carakasahita: Text with English Translation \& Critical Exposition Based on Cakrapi Datta's Ayurveda dpik, 1st ed. Varanasi, India: Chowkhamba Sanskrit Series Office, 197.

13. Plant authority: The Ayurvedic Pharmacopoeia of India Part - II (formulations). (2007). Government of India, Ministry of Health and Family Welfare Department of Ayurveda, Yoga \& Naturopathy, Unani, Siddha and Homoeopathy, New Delhi, 1(1), 140-141.

14. Natarajan S, Anbarasi C, Sathiyarajeswaran $\mathrm{P}$ et al. The efficacy of Siddha Medicine, KabasuraKudineer (KSK) compared to Vitamin C \& Zinc (CZ) supplementation in the management of asymptomatic COVID-19 cases: A structured summary of a study protocol for a randomised controlled trial. Trials 2020;21(1):892.

15. Srivastava A, Rengaraju M, Srivastava $S$ et al. A double blinded placebo controlled comparative clinical trial to evaluate the effectiveness of Siddha medicines, KabaSuraKudineer (KSK) \&NilavembuKudineer (NVK) along with standard Allopathy treatment in the management of symptomatic COVID 19 patients - a structured summary of a study protocol for a randomized controlled trial.Trials 2021;22(1):130.

16. Koppala N, Sunil K, Kallingil GD et al. Pharmacological Actions of Contents of Kabasura Kudineer- A Siddha Formulation for Fever with Respiratory Illness. Indian Journal of Pharmaceutical Education and Research. 2021;55(1).

17. Kumar S, Nair AS, Nair AM et al. Pharmacological and therapeutic effects of triphala - A literature review. Journal of Pharmacognosy and Phytochemistry. 2016; 5(3): 23-27.

18. Peterson CT, Denniston K, Chopra D. Therapeutic Uses of Triphala in Ayurvedic Medicine. The Journal of Alternative and Complementary Medicine. 2017; 8(23):607-614.

19. Negi J, Prashar B, Gupta J. Sitopaladi Churna as Anti-Tussive: A Review. International Journal of Health and Clinical Research. 2019;2(6):1-5.

20. Talwar S, Sood S, Kumar J et al. Ayurveda and Allopathic Therapeutic Strategies in Coronavirus Pandemic Treatment 2020. Curr Pharmacol. 2020; (6): 354-363.

21. Tamilnadu Government to distribute herbal concoction to boost immunity. Chennai, April 23,2020. Kabasura Kudineer will be distributed to over 1 lakh families living in COvid-19 containment zones.

https://www.thehindu.com/news/national/t amil-nadu/government-to-distributeherbal-concoction-to-boostimmunity/article31415335.ece. $\quad$ [last accessed on 23 April 2021] 
22. S.M. Chitra, P. Mallika, N. Anbu et al. An Open Clinical Evaluation of Selected Siddha regimen in expediting the management of Covid-19 -A Randomized Controlled Study. Journal of Ayurveda and Integrative Medicine, 2021; ISSN 0975-9476, https://doi.org/10.1016/j. jaim.2021.01.002.

23. Dania A, Maassen S, Maksim V et al. What makes (hydroxy) chloroquine ineffective against COVID-19: insights from cell biology Journal of Molecular Cell Biology, 2021; urlfile:///C:/Users/icmr/Downloads/Altulea Massen_Baranov_2021.pdf.[last accessed on 29 April 2021]

24. Jon Cohen, Kai Kupferschmidt. A very, very bad look' for remdesivir. Science. 2020;370(6517):642-643.

25. Elizabeth B Pathak. Convalescent plasma is ineffective for covid-9. BMJ 2020;371:m4072,http://dx.doi.org/10.1136 /bmj.m4072

26. Kumar PM, Sundaram MM, Ramasamy K. Coronavirus spike (S) glycoprotein (2019ncov) targeted siddha medicines kabasura kudineer and thonthasura kudineer -in silico evidence for corona viral drug. Asian J. Pharm. Res. Health Care. 2020;1(12): 20-27.

27. Rais A, Negi DS, Arya H, Verma Ret al. A Randomized open label parallel group pilot study to evaluate efficacy of Ayurveda interventions in the management of asymptomatic and mild
COVID-19 patients-experiences of a Lucknow based Level 2 hospital of Uttar Pradesh, India. https://doi.org/10.1016/j.jaim.2020.12.013

. Url- https://www.sciencedirect.com/ science/article/pii/S0975947620301431[1a st accessed on 24 April 2021]

28. Rao VV, Juneja A, Maulik M, Adhikari T et al. Emerging trends from COVID-19 research registered in the Clinical Trials Registry - India. IJMR, Ahead of print url-

https://www.ijmr.org.in/preprintarticle.asp ?id $=298626 ;$ type $=0$. [last accessed on 24 April 2021]

Conflict of interest: Author declares that there is no conflict of interest. Authors declare that there is absence of any commercial or financial relationships that could be contributed as a potential conflict of interest.

Guarantor: Corresponding author is guarantor of this article and its contents.

\section{Source of support: None}

\section{How to cite this article:}

Kumar N, Tripathi N, Nandave M. Management of Covid-19 patients with indigenous formulations in home settingsCase reports of two patients. Int. J. AYUSH CaRe. 2021; 5(2):98-106. 